\title{
CASE STUDY: A COMPARATIVE STUDY THE KARMUKA VEDIC PLANNING AND EXISTING CITY CENTRAL PLACE IN LATUR CITY IN INDIA
}

\author{
Ar. Priti V.Patwari \\ Department of Architecture and Interior Design \\ Dayanand Education Society, \\ Latur, Maharashtra, India
}

\begin{abstract}
Vedic style of architecture came into existence after the fall down of Indus valley civilization. Four Vedas were used Vedic principles of planning; those are Rig Veda, Sam Veda, Atharva Veda and Yajur Veda. The early examples of town planning have set an example of planed city which were for the welfare and development of the people. Karmuka was a type of bow shaped planning of city which was particularly for the towns where people were in trade. Ganj Golai is a type of city central circle which has various similarities of Karmuka planning. the aim of study is to compare both the planning which could be a live example of Vedic planning for study.
\end{abstract}

Keywords - Vedic planning, Karmuka, Bow Shape, Gamj Golai.

\section{INTRODUCTION}

Ganj Golai is in the city center. Latur town planner Faiyajuddin designed the "Ganjgolai ". The main building of the Golai is a huge two-storey structure which was constructed in the year 1917. At the center of the circular structure is Goddess Ambabai temple. There are 16 roads connecting to this golai ("roundabout") and along these roads are separate markets selling all kinds of conventional local wares like gold ornaments, footwear grocery from chili to jaggery. "Ganjgolai" is the main commercial and trade centre of Latur.

Town Planning

Town planning is an art of planning and civil architecture

Aim: A comparative study between the karmuka vedic planning and existing city central place.

Objective: Comparison of KARMUKA plan and Ganj golai layout.

Limitation: Study is limited to The Ganj Golai circle layout in Latur.

\section{TOWN PLANNING IN ANCIENT INDIA :}

Towns are the most complex things that human beings have created. In ancient India there were wellsprings of culture, technology, wealth and power. Early examples of planned urban development include orderly street systems that are rectilinear and radial; a city was divide into special functional quarters; development of commanding central sites for palaces, temples and civic buildings; with the advanced systems of fortification, water supply, and drainage. India has characteristically drifted with history, rising to accomplish great things. It has proven in town planning.

\section{VEDIC ARCHITECTURE}

The Vedic culture with Vedic style of architecture came into existence after the fall down of Indus valley civilization due to natural disasters and Aryan Invasion (1500BC-1000BC). These settlers were highly knowledgeable in the science of city planning. many cities were formed along the banks of rivers. Four Vedas were used Vedic principles of planning; those are Rig Veda, Sam Veda, Atharva Veda and Yajur Veda.

There are various treatise on architecture like the Vastu Shastra, Priccha, Manasollasa, Prasadamandana, Shilparatnam etc based on Vedic hymns. Cosmic and humans are linked in form of temples. The cities were laid according to various elements of Vedas:

- Sthapatya Veda - city layout

- Smriti Shastra : street layout on macro and micro level

- Vastu Shastra: building planning and design, site selection, service layout, landscaping and building orientation

-Arthashastra environmental management

According to the Mandala Vastu Shastra: 5 town shapes:

1. Chandura - square

2. Agatara - rectangle

3. Vritta - circle 


\section{International Journal of Engineering Applied Sciences and Technology, 2019 Vol. 4, Issue 5, ISSN No. 2455-2143, Pages 311-314 \\ Published Online September 2019 in IJEAST (http://www.ijeast.com)}

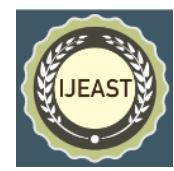

4. Kritta vritta - elliptical

5. Gola vritta - full circle

\section{LAYOUT IN MANASARA VASTUSHASTRA}

'Manasara'7 describes eight types of villages:

$\begin{array}{ll}\text { 1. } & \text { Dandaka } \\ \text { 2. } & \text { Svastika } \\ \text { 3. } & \text { Sarvatobhadra } \\ \text { 4. } & \text { Prastara } \\ \text { 5. } & \text { Nandyavarta } \\ \text { 6. } & \text { Karmuka } \\ \text { 7. } & \text { Pandmaka } \\ \text { 8. } & \text { Chaturmukh }\end{array}$

\section{KARMUKA: A BOW SHAPE LAYOUT}

This kind of layout is usually in semi-circle, parabolic or in a bow shape usually applied near the banks of the river or near the seashore. The main streets of the town are laid from north to south or east to west and the cross streets run at right-angles to them, dividing the whole area into blocks. The deity, commonly a female deity, is installed in the temple build in any convenient place.

\section{KARMUKA}

- This plan is suitable for the place where the site of the town is in the form of a bow or semi-circular or parabolic and mostly applied for towns located on the seashore or riverbanks.

The main streets of the town run from north to south or east to west and the cross streets run at right-angles to them, dividing the whole area into blocks.

- The presiding deity, commonly a female deity, is installed in the temple build in any convenient place.

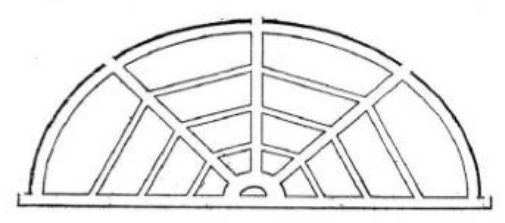

\section{TOWNS IN ACIENT PERIOD}

The town has its population is denser than in rural area and is settled in restricted area and is primarily in non agricultural in occupation. Town is dependent on rural areas for the supply of food and raw materials. The following are ten abstract criteria to distinguish the earliest city from any older or contemporary village

1. The size first towns must have been more extensive and more densely populated than any other previous settlements, 2.There might be peasants cultivating lands outside the town. All towns must have accommodated in addition nonfood producing classes-full-time specialist craftsmen, transport-workers, merchants, officials and priests-supported by the surplus produced by peasants. Each primary producer paid over his tiny surplus to a deity or divine king who thus concentrated the surplus. Truly monumental buildings distinguish each known town from the village but also symbolize the social surplus. Those not engaged in foodproduction were supported in by the surplus accomodated in temples or royal granaries and were dependent on the temple

VISVAKARMA VASTUSASTRA 13

Describes 20 types of towns among which one of them is Karmuka

1.Padma

3.Sarvatobhadra

5.Visvesbhadra

2.Devanagara

7.Karmuka

9.Prastara

11.Caturmukha

13. Balideva

15.Guha-nagara

17..Nandyavarta

4. Vaijayanata

6.Putabhedana

8.Jala-nagar

10.Swastika

12.Sripratisthita '

14.Pura

16.Astamukha

18. Rajadhani

19.Manusangara

20.Girinagara

\section{HISTORY : LATUR CITY}

Introduction: Latur is an important historical place of Marathwada region in Maharashtra. An ancient settlement located in the midst of Manjra and the Tawarja Valley. The Rashtrkuta king Amoghvarsa-I was the king of who developed the city. The Rashtrakutas succeeded the Chalukyas of Badami in $953 \mathrm{AD}$. They were the residents of Lattalur. (Old name of Latur)

The history of Latur can be divided into following periods.

Ancient period 2000 BC To 1317 A.D.

Muslim period 1317 A.D. To 1849 A.D.

British period 1849 A.D. To 1948 A.D.

Post independence 1948 A.D. Onwards

Ancient period

Satvahana Royal family were the first Royal family to develop supreme power in Maharashtra. They ruled major part of south India. No other dynasty ruled India around 460 years.

Political history, administration, religious and cultural, archaeology, sculpture, paintings, and literature information's are available for this period. There are records of Sanskrit and Jain literature Goldsmith of Ausa Dist. Latur has coins of Satvahana king (130 to 159 A.D.). this information proves that Latur and its surrounding was under Satvahana Empire.

ii) Chalukya dynasty

Chalukya Royal family emerged during $5^{\text {th }}$ century A.D. that ruled Karnataka and Maharashtra. Chalukya Empire was established by Vishnuvardhan,. 


\section{International Journal of Engineering Applied Sciences and Technology, 2019 Vol. 4, Issue 5, ISSN No. 2455-2143, Pages 311-314 \\ Published Online September 2019 in IJEAST (http://www.ijeast.com)}

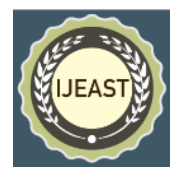

God and goddesses worshiped by this dynasty were Bagavati, Nandagauri, Kartikey, Narayana, Saptamatrika etc. Kharosa cave (Tal. Ausa Dist. Latur) includes stone of God Saptamatrika. At the beginning of Badami Chalukya in $6^{\text {th }}$ century A.D., Jaysingh, Ranarag (I), Pulkeshi (AD 535-563) Vinayaditya (AD 681-676) and Vijayditya (AD 696-733) ruled this region which is is indicated through copper plates found with the local people. After Badami Chalukya first person of Kalyani Chalukya is Tailap. Inscription of Latur is related to Kalyani Chalukya where reference of Latur is found as Lattalour. There is reference of Manjra river as Manjri river on two copper plates.

\section{iii) Kalpsamuha dynasty}

Latur is indicated by inscriptions, on the copper plates and carvings in Sanskrit, Marathi and Kanadi languages. There are references of Lattnour (Latur) Turre (Tururi), Sakhaval (Sakol), Ujala (Ujlamb), Kakharne (Kakhanal), Udagiri (Udgir) and Koney (Village Kanhegaon) which are located around Latur. In the Nagpur museum, there are evidence relating to Latur during AD 1894 having rule of Vikramaditya ( $\left.\mathrm{VI}^{\mathrm{th}}\right)$. It inscribes a note about of grant given by Maharashtrakutia Mandlik of Vikramaditya Mahasamant Dhadibhandaks Lattalour residence Dandanayak Vatragrotri Padmanaths son of Vasudeva.

\section{vi) Chalukya dynasty}

According to many scholars Bhadami and Kalyani Chalukas are the ancestors of Kalyani Chalukas. In book "Vikramankadeo Charit" written by Bilhan there are many references of this area. inscription of 1049 AD, Plavang Savatson, Falguna Shudha Ashtami, 10 February 1128 AD. which inscribes "Latalour" is used for Latur. reference of Manjari River is important with the reference of Dev River. References from Ganeshwadi inscription Anandi (Alandi Tal. Devani Dist. Latur) village Savarvalligram (Savali), Chandpuri (Chandori, Tal. Nilanga Dist. Latur), Belkonda (Belkunde), Kusunvadurigram (Kusanur Tal. Nilanga Dist. Latur).

There are reference of Chalukyas, Ahavamalla, Parmrdi and his son Bhulokmalla, the three generations in Latur inscriptions. Name "Lattalur" is important thus, Latur and its surroundings is an ancient as proved by inscriptions.

\section{v) Rashtrakuta dynasty}

"Rashtrakuta" suppose to be a place of political power, a name given to big region. The head of village is called as Gramkuta (Patil) and head of country as Kashtrakuta. Similarly Deshmukh, Sardeshmukh, Deshpande, Sardeshpande, Kulkarni and Pande were the heads of sub-regions during this dynasty and Chief of all these heads were called as Rashtrakuta who were known as king of the country. The concept of Rashtrkuta, name of Royal family is used right from $4^{\text {th }}$ century A.D. Samrat Amoghwarsh titled himself as Lattlurpuraradhishwar, as explained in inscriptions and copper plates.

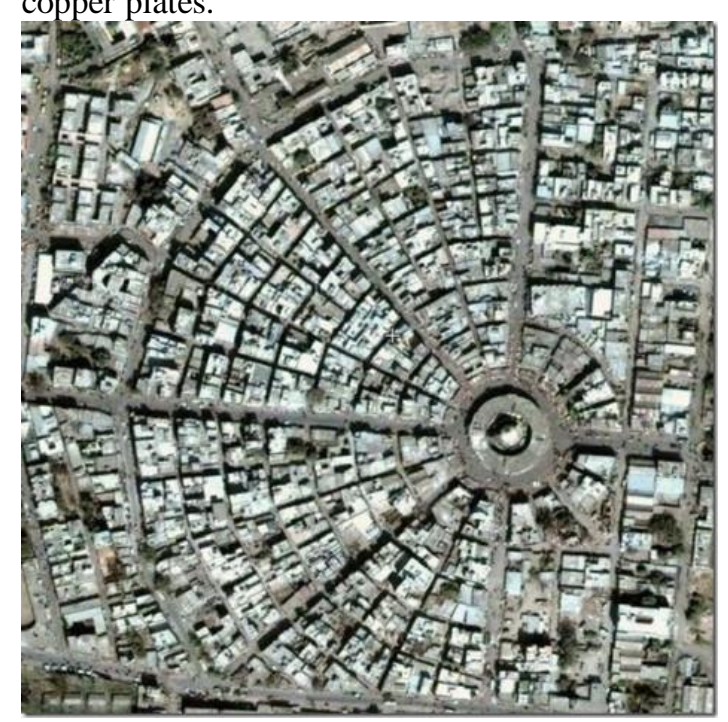

\section{EXISTING LAYOUT GANJ GOLAI}

\section{CONCLUSION}

The overall review of the literature concludes with comparison of various factors of the planning to KARMUKA type of Vedic planning and GANJ GOLAI. Though there are no evidence of karmuka planning referred for this type of layout, there are some factors which show the relation such as the female deity temple at the center, bow shaped planning, planning for the (vaisyas) merchant class (which at present include the Lingayat, Marwadis and the Komti clans). This kind of layout were usually on the banks of the river or seashore may be for the trade through water ways. As Latur is a trade centre and still a well-known town for the agricultural trade this layout must have been referred.

It can be a live example of Karmuka planning. fThe historic planning techniques were more effective which were as per the nature of the occupation, trade, culture of the people which held the basis of the modern planning and construction techniques.

Architecture and planning taught the world the importance of vernacular architecture and planning to be incorporated in modern day planning. The classic architecture styles of different parts of the world depict their rich and vibrant culture and traditions. It is important to adopt the classic styles of architecture for future as it will not only glorify India's and the various parts of the world's rich culture and traditions but also contribute to the environment around us. Architecture flourishes when we combine classical style of architecture with contemporary styles "Ganj golai" sets an example of the same. 
International Journal of Engineering Applied Sciences and Technology, 2019

Vol. 4, Issue 5, ISSN No. 2455-2143, Pages 311-314

Published Online September 2019 in IJEAST (http://www.ijeast.com)

\section{ACKNOWLEDGEMENTS:}

I want to thank every individual who assisted me, directly or indirectly in this paper.i wish to express gratitude towards them.

\section{REFERENCES}

1. The great ages of world architecture; authorG.K.Hiraskar

2. Sir Bannister Fletcher history of architecture.

3. Ar. Iram Aziz (2018):Vedic Principles Of Planning Of Temple Cities In India

4. http://shodhganga.inflibnet.ac.in/bitstream/10603/8599 5/11/11_chapter3.pdf

5. Images from google images.

6. http://zplatur.gov.in/htmldocs/leftframe/historicalPlace s.html

7. Ar. Sarkar Kaninika Dey (2016):"Historic architecture \& THe ancient art of planning The era forgotten"Civil Engineering and Urban Planning: An International Journal(CiVEJ) Vol.3,No.1, March 2016

8. Book: Manasara vol.3 